\title{
Pengaruh Ketepatan Kodefikasi Penyakit Terhadap Validasi Laporan Morbiditas Rawat Jalan di RS X
}

\section{The Influence Of Accuracy Of Codefication Of Disease Against Validation Of Outpatient Morbidity Report In RS X}

\author{
Ivana Putri Risyanti ${ }^{1)}$ \\ Syafira Atikah Yudianti2) \\ 1)Jurusan Rekam Medis dan Informasi Kesehatan ;Poltekkes Kemenkes Semarang \\ Jl. Tirto Agung ; Pedalangan ; Banyumanik ; Semarang \\ 2)Rumah Sakit Jiwa Prof. Dr. Soerojo Magelang \\ Jl. Ahmad Yani No.169, Kramat Utara, Kec. Magelang Utara, Kota Magelang \\ E-mail: ivana.setiawan86@gmail.com, syafirayudianti@gmail.com
}

\begin{abstract}
According to the WHO in 2004 the coding implementation must be complete and accurate according to the direction of ICD 10. The accuracy of the code is influenced by the determination or determination of the patient's diagnosis. If the diagnosis is not accurate, it will affect the number of cases in making reports of morbidity, mortality and the calculation of various statistics of the hospital. There is an outpatient coding officer at RS X and also duty to make report morbiditas while making report morbiditas made manually because SIMRS not able to present data needed. In addition, the implementation of codification is performed on the main diagnosis only and outpatient morbidity reports have not been well documented. The objective of this research is to know the effect of the outpatient code on the validation of outpatient morbidity report in RS X. This type of research uses analytic observation with Cross sectional approach. The population of this study is the number of outpatient cases in daily census outpatient dn report morbidity as many as 573 cases with total sampling technique. Statistical test using chi square on SPSS. The result of the research shows that there is an influence between the accuracy of disease codification on the validation of outpatient morbidity report in RS X with $p=0,000$.
\end{abstract}

Keywords : Accuracy of Code ; Morbidity Report; Outpatient

\begin{abstract}
Abstrak
Menurut WHO tahun 2004 pelaksanaan pengkodean harus lengkap dan akurat sesuai arahan ICD 10. Keakuratan kode dipengaruhi oleh penetapan atau penentuan diagnosis pasien. Apabila dalam mengode diagnosis tidak akurat maka akan berpengaruh pada jumlah kasus dalam pembuatan laporan morbiditas, mortalitas serta penghitungan berbagai angka statistik rumah sakit. Petugas koding rawat jalan di RS X berjumlah satu dan bertugas pula membuat laporan morbiditas sedangkan pembuatan laporan morbiditas dibuat secara manual karena SIMRS belum bisa menyajikan data yang dibutuhkan. Selain itu, pelaksanaan kodefikasi dilakukan pada diagnosis utama saja dan laporan morbiditas rawat jalan belum terdokumentasikan dengan baik. Tujuan penelitian adalah mengetahui pengaruh ketepatan kodefikasi penyakit rawat jalan terhadap validasi laporan morbiditas rawat jalan di RS X. Jenis penelitian menggunakan observasi analitik dengan pendekatan Cross sectional. Populasi penelitian ini adalah jumlah kasus rawat jalan pada sensus harian rawat jalan dn laporan morbiditas sebanyak 573 kasus dengan teknik pengambilan total sampling. Uji statistik menggunakan chi square pada SPSS. Hasil penelitian menunjukan ada pengaruh antara ketepatan kodefikasi penyakit terhadap validasi laporan morbiditas rawat jalan di RS X dengan nilai $p=0,000$.
\end{abstract}

Kata Kunci : Ketepatan Kode ; Laporan Morbiditas ; Rawat Jalan 


\section{Pendahuluan}

Menurut UU No.36 Tahun 2014 tentang Tenaga Kesehatan menyebutkan setiap fasilitas penyelenggara pelayanan kesehatan wajib menyelenggarakan rekam medis. Rekam medis adalah berkas yang berisikan catatan dan dokumen tentang identitas pasien, pemeriksaan, pengobatan, tindakan dan pelayanan lain yang telah diberikan pada pasien. Rekam medis pasien harus segera dilengkapi setelah pasien selesai menerima pelayanan kesehatan. Kelengkapan rekam medis sangat penting peranannya yaitu untuk pendokumentasian data medis pasien serta pengolahan dan pelaporan data medis pasien yang akurat.

Perekam Medis mempunyai

kewenangan melaksanakan sistem klasifikasi klinis dan kodefikasi penyakit yang berkaitan dengan kesehatan dan tindakan medis sesuai terminologi medis yang benar, melaksanakan indeks dengan cara mengumpulkan data penyakit, kematian, tindakan dan dokter yang dikelompokkan pada indeks, melaksanakan sistem pelaporan dalam bentuk informasi kegiatan pelayanan kesehatan (Permenkes No.55 Tahun 2013).

Salah satu jenis pelaporan rumah sakit adalah RL4b yaitu pelaporan tentang data keadaan morbiditas pasien rawat jalan yang merupakan formulir rekapitulasi dari jumlah kasus baru dan jumlah kunjungan yang terdapat pada unit rawat jalan Rumah Sakit untuk Tahunan (Permenkes No. 1171/MENKES/PER/VI/2011). RL4b

disusun berdasarkan data dari Health Information System (HIS) rumah sakit dan Indeks Penyakit dan tindakan pasien rawat jalan. Indeks penyakit dan tindakan pasien disusun berdasarkan diagnosis penyakit dan tindakan oleh dokter yang tertulis di rekam medis dalam bentuk kode diagnosa penyakit dan tindakan.

Menurut WHO tahun 2004 pelaksanaan pengkodean harus lengkap dan akurat sesuai arahan ICD10. Keakuratan kode dipengaruhi oleh penetapan atau penentuan diagnosis pasien. Apabila dalam mengode diagnosis tidak akurat maka akan berpengaruh pada jumlah kasus

dalam pembuatan laporan morbiditas, mortalitas serta penghitungan berbagai angka statistik rumah sakit.

Berdasarkan hasil studi pendahuluan pelaporan internal RS X, diketahui bahwa di RS $X$ petugas kodefikasi rawat jalan berjumlah satu dan bertugas pula membuat laporan morbiditas sedangkan pembuatan laporan morbiditas dibuat secara manual karena SIMRS belum bisa menyajikan data yang dibutuhkan. Selain itu, laporan morbiditas rawat jalan belum terdokumentasikan dengan baik.

Pada bulan juni 2016 diketahui kasus diabetes melitus sejumlah 2487 pasien, namun tidak dijelaskan lebih lanjut apakah diabetes mellitus tipe I, tipe 2, atau diabetes mellitus without complication. Didasari keingintahuan peneliti apakah terdapat hubungan antara ketepatan kodefikasi penyakit dengan validasi laporan morbiditas penyakit dan tindakan rawat jalan di RS $\mathrm{X}$, maka penulis tertarik untuk mengambil judul "Pengaruh Ketepatan Kodefikasi Penyakit Terhadap Validasi Laporan Morbiditas Rawat Jalan di RS X."

\section{Metode}

Penelitian ini menggunakan jenis penelitian analitik observasional yaitu untuk mengetahui hubungan sebab akibat antara dua variabel secara observasional, dimana bentuk hubungan dapat: perbedaan, hubungan atau pengaruh dengan pendekatan cross-sectional. Penelitian ini menggunakan total sampling 573 kasus rawat jalan pada sensus harian rawat jalan dan laporan morbiditas bulan Agustus - Oktober 2017. Instrumen yang digunakan adalah tabel penelitian dan panduan wawancara. Variabel penelitian independen adalah ketepatan kodefikasi penyakit rawat jalan dan variabel dependen adalah validasi laporan morbiditas rawat jalan di RS $X$. 
Ketepatan kodefikasi penyakit rawat jalan adalah kode penyakit rawat jalan yang dikodefikasi berdasarkan diagnosis utama maupun sekunder berdasarkan kaidah koding dengan menggunakan ICD-10 volume 1 dan 3. Validasi laporan morbiditas rawat jalan adalah kesesuaian pengisian laporan morbiditas rawat jalan bahwa diagnosis rawat jalan yang sudah dikodefikasi dimasukkan kedalam laporan morbiditas rawat jalan sesuai dengan kolom yang sudah tersedia. Pengaruh kodefikasi penyakit rawat jalan dengan validasi laporan morbiditas rawat jalanadalah Adanya pengaruh antara hasil kodefikasi rawat jalan dengan kesesuaian pengisian laporan morbiditas rawat jalan dengan menggunakan uji chi square.

\section{Hasil dan Pembahasan}

Hasil analisisi tingkat/prosentase ketepatan kode diagnosis rawat jalan di RS $X$ dari Poli Dalam 1 dan 2 adalah sebagai berikut:

Tabel 1 Ketepatan Kode Rawat Jalan di RS X

\begin{tabular}{cccc}
\hline No. & Kategori & Jumlah & $\begin{array}{c}\text { Prosentase } \\
(\%)\end{array}$ \\
\hline 1 & Tepat & 362 & $63,2 \%$ \\
2 & Tidak Tepat & 211 & $36,8 \%$ \\
& Total & 573 & $100 \%$ \\
\hline
\end{tabular}

Tabel 2. Ketepatan Pengisian Laporan Morbiditas Rawat Jalan di RS X

\begin{tabular}{cccc}
\hline No. & Kategori & Jumlah & $\begin{array}{c}\text { Prosentase } \\
(\%)\end{array}$ \\
\hline 1 & Tepat & 527 & $92 \%$ \\
2 & Tidak & 46 & $8 \%$ \\
& Tepat & 573 & $100 \%$ \\
\hline
\end{tabular}

Tabel 3 Data Kesesuaian Kode dengan Laporan Morbiditas

\begin{tabular}{ccccccc}
\hline \multicolumn{7}{c}{ Laporan } \\
Morbiditas \\
\hline \multirow{3}{*}{ Kode RS Tepat } & \multicolumn{3}{c}{$\begin{array}{c}\text { Tidak } \\
\text { Tidat }\end{array}$} & \multicolumn{1}{c}{ Jumlah } \\
\cline { 2 - 7 } & \multicolumn{1}{c}{ Tepat } & F & $\%$ & F & $\%$ \\
\hline Tepat & 317 & 55 & 45 & 8 & 363 & 63 \\
Tidak & 211 & 37 & 0 & 0 & 210 & 37 \\
Tepat & & & & & & \\
Jumlah & 528 & 92 & 45 & 8 & 573 & 100
\end{tabular}

Berdasarkan Tabel 1 menggambarkan bahwa tingkat ketepatan kode rawat jalan adalah 362 diagnosis $(63,2 \%)$ dan yang tidak tepat sebanyak $211 \quad(36,8 \%)$. Ketidaktepatan kode diagnosis rawat jalan di RS X yaitu disebabkan oleh penggunaan dan pemilihan karakter keempat yang tidak sesuai dengan diagnosis sekunder.

Ketidaktepatan tersebut merupakan salah satu kekurangtelitian seorang coder dalam menentukan kode karena untuk menentukan kode diagnosis tidak hanya mengacu pada ICD-10 Volume 3 saja, namun juga harus merujuk pada ICD-10 Volume 1. Seperti pernyataan Kasim (2011), bahwa setelah menentukan kode pada ICD- 10 Volume 3, perlu melihat daftar tabulasi (ICD-10 Volume 1) untuk mencari kode yang paling tepat.

Penggunaan kode karakter keempat selain ketidaktelitian seorang coder juga karena dalam pemberian kode diagnosis tidak menggunakan buku ICD-10 baik volume 1 ataupun volume 3. Coder memberikan kode diagnosis dengan cara mengulang kembali pengalaman yang diperoleh dalam memecahkan permasalahan yang dihadapi pada masa lalu atau didasarkan pada hal-hal yang biasanya terjadi (kebiasaan). Dengan kata lain, pemberian kode dilakukan secara berulang, menjawab karena kebiasaan melihat diagnosis yang sering ada pada dokumen rekam medis, sehingga hal ini juga akan mempengaruhi tingkat ketepatan pemberian kode diagnosis. Sebagai contoh, pada diagnosis Non Insulin Dependent Diabetes Mellitus kode diagnosis di RS X, yaitu E14, padahal kode berdasarkan ICD-10 E11. Coder memberikan kode diagnosis ini E11 karena kebiasan dan pengetahuan mereka jika diabetes mellitus maka kodenya E14, diagnosis ini merupakan 10 besar penyakit di RS $X$ sehingga banyak dokumen rekam medis dengan kode diagnosis E14. 
Prosentase ketepatan pengisian laporan morbiditas rawat jalan di RS $X$ diperoleh dari laporan morbiditas rawat jalan di RS $X$ sebanyak 573 diagnosis penyakit rawat jalan.

Berdasarkan Tabel 2 didapatkan hasil prosentase tertinggi yaitu bahwa dalam pengisian laporan morbiditas rawat jalan di RS X lebih banyak yang tepat sebanyak 527 (92\%) daripada yang tidak tepat sebanyak 46 (8\%). Ketidaktepatan pengisian laporan morbiditas rawat jalan sebanyak $8 \%$ dikarenakan kode penyakit rawat jalan yang sudah dikoding tidak tercantum kedalam laporan morbiditas sesuai dengan Juknis SIRS 2011. Kode diagnosis terbanyak yang tidak dapat tersaji kedalam laporan morbiditas adalah kode I51.9 ( Chronic Heart Failure).

Pada penelitian ini terdapat pengaruh antara ketepatan kodefikasi penyakit terhadap validasi laporan morbiditas rawat jalan di RS X dengan nilai $p=0.000$ dengan menggunakan uji chi square pada SPSS. Ketepatan penulisan diagnosis sangat berpengaruh terhadap administrasi rumah sakit. Karena sebagai tujuan utama rekam medis adalah untuk menunjang tercapainya tertib administrasi dalam upaya peningkatan pelayanan kesehatan di rumah sakit, tanpa didukung suatu sistem pengelolaan rekam medis yang baik dan benar, tertib administrasi rumah sakit tidak akan berhasil sebagaimana yang diharapkan. Majunya teknologi informasi, kegunaan rekam medis dapat dilihat dalam 2 kelompok besar. Pertama, yang paling berhubungan langsung dengan pelayanan pasien (primer). Kedua, yang berkaitan dengan lingkungan seputar pelayanan pasien (sekunder) (Hatta, 2011).

\section{Simpulan dan Saran}

Dari 573 kode diagnosis rawat jalan di RS X diketahui bahwa kode diagnosis rawat jalan yang tepat sejumlah $362(63,2 \%)$ dan yang tidak tepat sejumlah 211 (36,8\%). Pengisian laporan morbiditas yang sesuai sebanyak 527 (92\%) dan yang tidak sesuai sebanyak 46 (8\%) dari 573 kasus penyakit dalam rawat jalan. Terdapat pengaruh antara ketepatan kode penyakit rawat jalan dengan laporan morbiditas rawat jalan di RS X yaitu dengan nilai $p=0,000$. Saran dari penelitian ini adalah pelaksanaan kodefikasi rawat jalan berdasarkan diagnosis yang ada di rekam medis pasien rawat jalan bukan berdasarkan sensus harian rawat jalan dan membuat Standar Operasional Prosedur tentang laporan morbiditas rawat jalan.

\section{Daftar Pustaka}

Direktorat Jenderal Bina Upaya Kesehatan. Juknis Sistem Informasi Rumah Sakit. 2011. Jakarta: Menkes RI

Hatta, Gemala.R. (2012). Pedoman Manajemen Informasi Kesehatan di sarana pelayanan kesehatan. Jakarta: Penerbit Universitas Jakarta

Kartikasari, Diah A. 2016. Faktor-Faktor yang Mempengaruhi Ketepatan Pengkodean Diagnosis Pasien Rawat Inap pada Kasus Intracranial Injury di RSUD Prof. DR. Margono Soekarjo Purwokerto Periode Tahun 2015. Semarang : Poltekkes Kemenkes Semarang.

Latifah Hanum. Hambatan Pembuatan Laporan Morbiditas Pasien Rawat Jalan di Rumah Sakit Umum Daerah (RSUD)

Sleman. 2014. Yogyakarta : Universitas Gadjah Mada.

Mathis R.L dan Jackson J.H, 2002. Manajemen Sumber Daya Manusia, Jakarta : Salemba Empat

National Center for Health Statistics. 2008. International Classification of Disease, Tenth Revision (ICD-10). Diunduh : 23 Februari 2016

Internet :http://www.cdc.gov/ nchs/about/ma

jor/dvc/icd10des.htm.

Notoatmodjo, S. (2012). Metodologi Penelitian Kesehatan. Jakarta: Rineka Cipta 
Oktrina Dian, P. Pelaksanaan Pembuatan Dan Pengiriman Laporan Data Keadaan Morbiditas dan Mortalitas Pasien Rawat Inap (RL4a) di RSJ Grhasia DIY. 2014. Yogyakarta : Universitas Gadjah Mada.

Peraturan Menteri Kesehatan Republik Indonesia No. 55 Tahun 2013 tentang Penyelenggaraan Rekam Medis dan Informasi Kesehatan. 2013. Jakarta: Menkes RI

Peraturan Menteri Kesehatan Republik Indonesia No. 269/Menkes/SK /III/ 2008 tentang Rekam Medis. 2008. Jakarta: Menkes RI

Peraturan Menteri Kesehatan Republik Indonesia No. 290/Menkes /Per/III/2008 tentang Persetujuan

Tindakan Kedokteran. 2008. Jakarta: Menkes RI

Peraturan Menteri Kesehatan Republik Indonesia No. 377/Menkes /Per/III/2007 tentang Standar Profesi Perekam Medis dan Informasi Kesehatan. 2007. Jakarta: Menkes RI
Undang-undang Republik Indonesia Nomor 36 Tahun 2009 tentang Kesehatan

Undang-undang Republik Indonesia Nomor 36 Tahun 2014 tentang Tenaga Kesehatan

Wawan, A dan M, Dewi. (2011). Teori \& Pengukuran PENGETAHUAN, SIKAP, DAN PERILAKU MANUSIA. Yogyakarta: Nuha Medika

World Health Organization, 2004. International Statistical Classification od Dissease and Related Health Problems Tenth Revision Volume 2 second edition. Geneva: World Health Organization

www.indonesian-publichealth.com, tentang Unsur-Unsur Managemen diakses pada tanggal 27 Februari 2016

www.hakayuci.com, tentang Sistem kodefikasi, diakses pada tanggal 2 Maret 2016 
